\title{
Pregnancy with adnexal masses: an institutional experience and review of the literature
}

\section{Anupama Bahadur, Modalavalasa Swetha Sri, Rajlaxmi Mundhra*, Latika Chawla, Megha Ajmani, Tuba Afreen, Payal Kumari, Shloka Sharma}

Department of Obstetrics and Gynecology, All India Institute of Medical Sciences Rishikesh, Uttarakhand, India

Received: 21 December 2020

Accepted: 04 February 2021

\section{*Correspondence:}

Dr. Rajlaxmi Mundhra,

E-mail: rmundhra54@yahoo.com

Copyright: () the author(s), publisher and licensee Medip Academy. This is an open-access article distributed under the terms of the Creative Commons Attribution Non-Commercial License, which permits unrestricted non-commercial use, distribution, and reproduction in any medium, provided the original work is properly cited.

\begin{abstract}
Adnexal masses in pregnancy are not uncommon. We prospectively analysed all cases with adnexal masses detected during pregnancy presented to our antenatal outpatient department from January 2019 to August 2020. Herein we report six such cases with their pregnancy outcome. Among the 6 cases, 3 were diagnosed during first trimester of pregnancy, 2 in third trimester and 1 was found incidentally during caesarean section. The mean age of the cases was $25.33+2.33$ years. Two cases underwent oophorectomy and rest had ovarian cystectomy. In terms of histopathological findings, one was endometriotic cyst, two were borderline tumors (mucinous and serous variety) and three were mature cystic teratomas. There was no perinatal mortality, but 2 babies required NICU admission for observation. Mature cystic teratoma was the most common adnexal mass detected in our series. Timing of surgery depends on urgency of situation. Asymptomatic/small/unilocular cyst with low suspicion should be kept under observation and follow up throughout pregnancy.
\end{abstract}

Keywords: Adnexal mass, Pregnancy, Mature cystic teratoma, Surgery

\section{INTRODUCTION}

Most of the adnexal masses are ovarian in origin, however masses arising from fallopian tubes, uterus, and non-gynaecological tissues can also be seen. ${ }^{1,2}$ Adnexal masses in pregnancy are a rare finding and most of these are discovered incidentally. The prevalence of adnexal masses in pregnancy is observed to be around 0.19$8.8 \%$. $^{3}$ Functional cysts and luteomas are the most common ovarian masses detected during pregnancy. ${ }^{4}$ The other ovarian masses are benign cystic teratomas, serous cystadenoma, para ovarian cyst, mucinous cystadenoma and endometrioma. ${ }^{5}$ Majority of these remain asymptomatic and can be managed conservatively. Functional cysts usually regress spontaneously but in masses which persist, there is a risk related to cyst torsion, rupture, labour obstruction, and malignancy.
Surgical intervention has been seen in around $1 \%$ to $2.3 \%$ of these cases. ${ }^{4,6}$

With current study, it was aimed to identify patients with adnexal masses detected during pregnancy and to evaluate their clinical presentation, histological diagnosis and pregnancy outcome.

\section{CASE SERIES}

All cases with adnexal masses detected during pregnancy in department of obstetrics and gynaecology, AIIMS Rishikesh from January 2019 to August 2020 were prospectively analysed. Women with cysts that spontaneously resolved by 12 weeks gestation were excluded. 
During the study period, there were 6 such cases with persistent adnexal masses in pregnancy were noted out of 870 pregnancy cases. The mean age of the cases was $25.33 \pm 2.33$ years (Table 1$)$.

Among the 6 cases, 3 were diagnosed in first trimester of pregnancy, 2 were diagnosed in third trimester and 1 was found incidentally during caesarean section. Cyst was unilateral in all six cases. None of the cases has intraoperative or preoperative cyst rupture. Two cases underwent salpingo-oophorectomy and rest had ovarian cystectomy. In terms of histopathological findings, one was endometriotic cyst, two were borderline tumors (mucinous and serous variety) and three were mature cystic teratomas (Table 2).

Out of 6 cases, 2 required premature termination of pregnancy. One was due to severe pre-eclampsia. The other was due to persistent and increased pain abdomen due to torsion of ovarian cyst with fetal growth restriction. All other cases were operated at term. There was no perinatal mortality, but 2 babies required NICU admission for observation (Table 3).

Table 1: Base line characteristics of study population.

\begin{tabular}{|lllllll|}
\hline Case $\mathbf{1}$ & Case 2 & Case 3 & Case 4 & Case 5 & Case 6 \\
\hline Parity (N) & 23 & 25 & 27 & 25 & 23 & 29 \\
\hline $\begin{array}{l}\text { Hypertensive } \\
\text { disorders }\end{array}$ & Primigravida & Primigravida & G4P3L3 & Primigravida & Primigravida & Primigravida \\
\hline Hypothyroidism & No & Yes & No & No & No & No \\
\hline
\end{tabular}

Table 2: Cyst related data.

\begin{tabular}{|c|c|c|c|c|c|c|}
\hline & Case 1 & Case 2 & Case 3 & Case 4 & Case 5 & Case 6 \\
\hline $\begin{array}{l}\text { Gestational } \\
\text { age at } \\
\text { presentation } \\
\text { (weeks) }\end{array}$ & $29^{+2}$ weeks & $11^{+1}$ weeks & $41^{+3}$ weeks & $36^{+4}$ weeks & 9 weeks & $6^{+4}$ weeks \\
\hline Size of cyst & $15 \times 10 \mathrm{~cm}$ & $16 \times 15 \mathrm{~cm}$ & $5 \times 4 \mathrm{~cm}$ & $6 \times 4 \mathrm{~cm}$ & $7 \times 6 \mathrm{~cm}$ & $10 \times 10 \mathrm{~cm}$ \\
\hline Laterality & Unilateral & Unilateral & Unilateral & Unilateral & Unilateral & Unilateral \\
\hline $\begin{array}{l}\text { Intra operative } \\
\text { cyst rupture }\end{array}$ & No & No & No & No & No & No \\
\hline $\begin{array}{l}\text { Ovarian } \\
\text { torsion }\end{array}$ & Yes & No & No & No & No & No \\
\hline $\begin{array}{l}\text { Tumor marker } \\
\text { CA125 } \\
\text { Ca 19-9 }\end{array}$ & $\begin{array}{l}\text { Normal } \\
\text { Normal }\end{array}$ & $\begin{array}{l}\text { Normal } \\
\text { Raised }\end{array}$ & $\begin{array}{l}- \\
-\end{array}$ & $\begin{array}{l}- \\
-\end{array}$ & $\begin{array}{l}\text { Normal } \\
\text { Normal }\end{array}$ & $\begin{array}{l}\text { Raised } \\
\text { Normal }\end{array}$ \\
\hline $\begin{array}{l}\text { Loculations/Se } \\
\text { pta }\end{array}$ & $\begin{array}{l}\text { Unilocular/ No } \\
\text { septa }\end{array}$ & Multilocular & - & - & - & Unilocular \\
\hline $\begin{array}{l}\text { Histo } \\
\text { pathology }\end{array}$ & $\begin{array}{l}\text { Endometriotic } \\
\text { cyst } \\
\text { (Chocolate } \\
\text { cyst). }\end{array}$ & $\begin{array}{l}\text { Borderline } \\
\text { mucinous } \\
\text { tumour. }\end{array}$ & $\begin{array}{l}\text { Mature } \\
\text { cystic } \\
\text { teratoma } \\
\text { (dermoid } \\
\text { cyst). }\end{array}$ & $\begin{array}{l}\text { Mature cystic } \\
\text { teratoma } \\
\text { (dermoid cyst). }\end{array}$ & $\begin{array}{l}\text { Mature cystic } \\
\text { teratoma } \\
\text { (dermoid } \\
\text { cyst). }\end{array}$ & $\begin{array}{l}\text { Serous } \\
\text { borderline } \\
\text { tumour }\end{array}$ \\
\hline
\end{tabular}

\section{Case 1}

A 25 years old primigravida presented at $29^{+2}$ weeks gestation with lower abdominal pain for 3 days. On per abdominal examination revealed $15 \times 12 \mathrm{~cm}$ cystic mass on left side of abdomen with mild tenderness displacing the gravid uterus to right. Ultrasound showed a large well defined $15 \times 14 \times 10 \mathrm{~cm}$ cystic lesion with ground glass echoes and no internal septations is noted in left adnexa with a growth restricted fetus. Magnetic resonance imaging (MRI) was done to evaluate lesion characteristics, extension and compression of adjacent structures and resectability.

MRI revealed a $\mathrm{T} 1$ hyperintense/ $\mathrm{T} 2$ hypointense lesion of $15 \times 11 \times 8 \mathrm{~cm}$ in left adnexal region extending into left iliac fossa. Left ovary is not separately seen. CA 125 was 28.7 U/ml. Other tumor markers like LDH, AFP, CEA, 
CA 19.9 were also within normal limit. Patient was kept on conservative management with routine antenatal follow ups. She underwent emergency laparotomy with caesarean delivery at 32 weeks 6 days of gestation in view of suspected torsion of the cyst. Premature delivery was also done in view of severe growth restricted fetus. Per operatively, a $15 \times 10 \mathrm{~cm}$ twisted left ovarian cyst was seen along with gravid uterus (Figure 1).

The left tube was stretched over the mass. Right ovary was apparently healthy. A live baby weighing $1.825 \mathrm{~kg}$ was delivered by a caesarean section with an APGAR score; $8 / 1$ minute and $9 / 5$ minute and shifted to the neonatal intensive care unit (NICU) for prematurity and fetal growth restriction. Left ovarian cystectomy was done. On cut section uniloculated filled with brownish fluid. Histopathology was suggestive of endometriotic cyst.

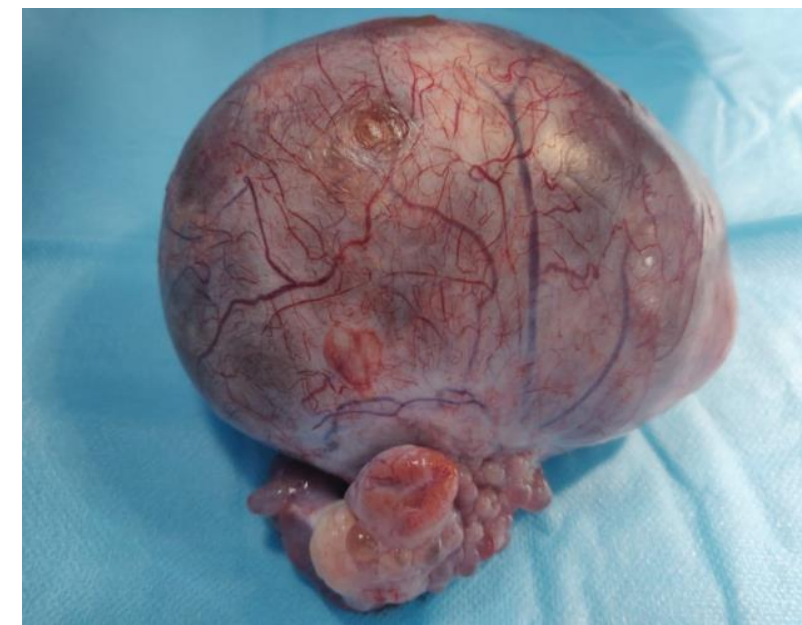

Figure 1: Per operative finding of ovarian cyst.

Table 3: Infant characteristics at delivery.

\begin{tabular}{|c|c|c|c|c|c|c|}
\hline & Case 1 & Case 2 & Case 3 & Case 4 & Case 5 & Case 6 \\
\hline $\begin{array}{l}\text { Gestational } \\
\text { weeks at } \\
\text { delivery } \\
\text { (weeks) }\end{array}$ & $32^{+6}$ week & $35^{+3}$ week & $41^{+3}$ week & 41 weeks & $37^{+6}$ week & 39 weeks \\
\hline $\begin{array}{l}\text { Type of } \\
\text { delivery }\end{array}$ & $\begin{array}{l}\text { Caesarean } \\
\text { section + } \\
\text { Left } \\
\text { ovarian } \\
\text { cystectomy }\end{array}$ & $\begin{array}{l}\text { Emergency } \\
\text { Caesarean } \\
\text { section + Left } \\
\text { salpingo } \\
\text { oophorectomy }\end{array}$ & $\begin{array}{l}\text { Emergency } \\
\text { Caesarean } \\
\text { section + } \\
\text { Left } \\
\text { ovarian } \\
\text { cystectomy }\end{array}$ & $\begin{array}{l}\text { Elective } \\
\text { Caesarean } \\
\text { section + Left } \\
\text { ovarian } \\
\text { cystectomy }\end{array}$ & $\begin{array}{l}\text { Emergency } \\
\text { Caesarean } \\
\text { section + Left } \\
\text { oophorectomy }\end{array}$ & $\begin{array}{l}\text { Emergency } \\
\text { Caesarean section }\end{array}$ \\
\hline Birth weight & $1.825 \mathrm{~kg}$ & $2.29 \mathrm{~kg}$ & $4.083 \mathrm{~kg}$ & $3.31 \mathrm{~kg}$ & $2.86 \mathrm{~kg}$ & $3.2 \mathrm{~kg}$ \\
\hline $\begin{array}{l}\text { APGAR } \\
\text { score in } \\
1 \text { min }\end{array}$ & 8 & 8 & 8 & 8 & 8 & 7 \\
\hline $\begin{array}{l}\text { APGAR } \\
\text { score in } \\
5 \text { min }\end{array}$ & 9 & 9 & 9 & 9 & 9 & 8 \\
\hline $\begin{array}{l}\text { NICU } \\
\text { admission }\end{array}$ & Yes & No & No & No & No & Yes \\
\hline
\end{tabular}

\section{Case 2}

A 25 years old primigravida at 11 weeks of gestation presented to our OPD with an ultrasound suggestive of large multiloculated cyst of $13.8 \times 10 \mathrm{~cm}$ with peripheral mural hyperechoic specks, low level internal echoes, no septa, no significant vascularity on doppler evaluation in the left adnexal region. Her past history was unremarkable. MRI pelvis showed well defined heterogenous multiloculated cystic lesion $15.8 \times 13 \times 12.5$ $\mathrm{cm}$ on left side of abdomen with no separate visualization of left ovary, fine internal septations with irregular thickening on septations. Besides other antenatal investigations, tumour markers such as CA 19-9 (347
U/ml), CA 125 (26 U/ml), CEA (0.63) and AFP (190) were done. She followed up regularly and her antenatal period was uneventful. She underwent emergency caesarean section at 35 weeks of gestation in view of severe preeclampsia with poor Bishops score. A $2.29 \mathrm{~kg}$ live infant with an APGAR score; 8 in 1 minute and 9 in 5 minutes was delivered. Per operatively, a $16 \times 15 \mathrm{~cm}$ multiloculated ovarian mass was seen on left side. Right ovary was apparently healthy, and all other intraabdominal organs seems healthy. Left salpingooophorectomy was done. On cut section thick mucoid material seen. Histopathological report showed Borderline mucinous tumour. Patient was kept on followup. 


\section{Case 3}

A 27 years old G4P3L3 at $41^{+3}$ week of gestation presented to our emergency department with labor pains. On per abdominal examination, term pregnancy with contractions and FHR present. On per vaginal examination, she was found to be in active labor. She underwent emergency caesarean section in view of cephalopelvic disproportion. A healthy live baby with a birth weight of $4.083 \mathrm{~kg}$ and the APGAR scores measured at 1 minute and 5 minutes were 8 and 9 respectively was delivered. Intra operatively, a left-sided ovarian cyst was observed measuring $5 \times 4 \mathrm{~cm}$. Left ovarian cystectomy was performed. Right ovary was apparently healthy. Histopathology revealed a mature cystic teratoma.

\section{Case 4}

A 27 years old primigravida presented at 41 weeks gestation with ultrasound finding of left ovarian cyst of $5.6 \times 4 \mathrm{~cm}$ with medial hyperechogenecity with shadowing and lateral cystic component noted. No significant vascularity on doppler evaluation. Right adnexa normal. No free fluid noted. Her antenatal period was uneventful. She was taken for caesarean section in view of failed induction. She delivered a $3.3 \mathrm{~kg}$ infant and the APGAR scores measured at 1 minute and 5 minutes were 8 and 9 respectively. Per operatively a $6 \times 4 \mathrm{~cm}$ cyst was identified originating from the left ovary. Right ovary was apparently healthy. Left ovarian cystectomy done. On cut section serous fluid drained, hair with solid areas was noted. Histopathological examination revealed a mature cystic teratoma (dermoid cyst).

\section{Case 5}

A 23 years old primigravida presented at 9 weeks of gestation with an ultrasound showing a gravid uterus with live fetus corresponding to $8^{+5}$ weeks of gestation and a $6.6 \times 6.1 \mathrm{~cm}$ left adnexal solic cystic mass with internal echoes and no significant vascularity on doppler evaluation. No right adnexal lesion noted. No free fluid in pouch of douglas. MRI showed a left ovarian cyst of $5.8 \times 5.4 \times 5.2 \mathrm{~cm}$ with $\mathrm{T} 1$ hyperintense fat foci which got suppressed on fat suppresses sequences likely representing dermoid (Figure 2). She was managed conservatively and received routine antenatal check-ups. All her tumor marker were within normal limits. At $37^{+6}$ weeks of gestation, she underwent emergency caesarean section for severe oligohydramnios (AFI-3). She delivered a $2.86 \mathrm{~kg}$ infant with APGAR scores of 8 and 9 at 1 minute and 5 minutes respectively. Peroperatively, a $7 \times 6 \mathrm{~cm}$ cyst was seen arising from the left ovary. Left oophorectomy was done as cyst cannot be separated from ovary. Right ovary was apparently healthy. Histopathology revealed mature cystic teratoma (dermoid cyst).

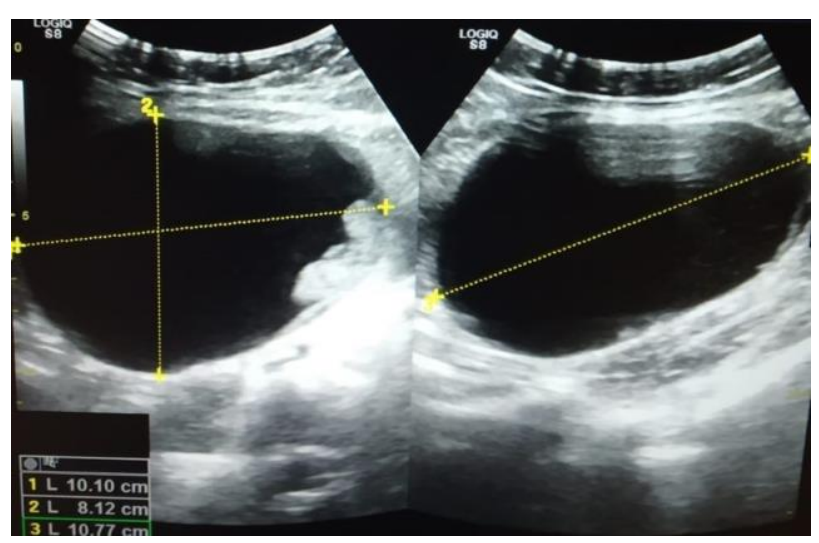

Figure 2: MRI of ovarian dermoid cyst.

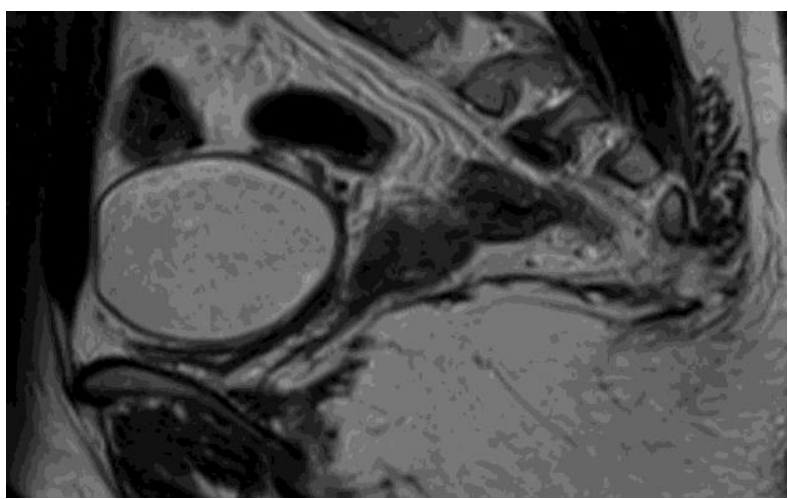

Figure 3: Ultrasound of right adnexal mass.

\section{Case 6}

A 29 year old primigravida at $6^{+4}$ weeks of gestation presented with an ultrasound suggestive of intrauterine gravid uterus and a cystic lesion of $10 \times 8 \times 10 \mathrm{~cm}$ in right adnexal region with internal echoes (Figure 3). MRI pelvis was done for cyst showed well defined unilocular cystic lesion of $10.1 \times 9.4 \times 7.7 \mathrm{~cm}$ on right adnexal region with multiple areas of soft tissue components seen within the lesion. Right ovary was not seen separately from the mass lesion. Besides other antenatal investigations, tumour markers such as CA 19-9 (0.36 U/ml), CA 125 (90.9 U/ml), CEA (0.94) and AFP (6.45) were done. In view of increasing size of the cyst and its suspicious nature, she underwent exploratory laparotomy at $14^{+2}$ weeks of gestation. Per operatively, gravid uterus of 14 weeks was found. No free fluid noted, but peritoneal washing was taken for cytological evaluation. A 10x10 $\mathrm{cm}$ right cystic ovarian mass with polypoidal growth on surface and edematous right fallopian tube was noted, Right salpingo oophrectomy done (Figure 4). Left ovary and fallopian tube were apparently healthy and all other intra abdominal organs also seemed normal. Histopathological report showed serous borderline tumour. Postoperative period was uneventful. She underwent emergency caesarean section at 39 weeks of gestation in view of foetal distress. A $3.2 \mathrm{~kg}$ infant with APGAR scores of 7 and 8 at 1 minute and 5 minutes 
respectively was delivered. Baby was shifted to NICU for observation.

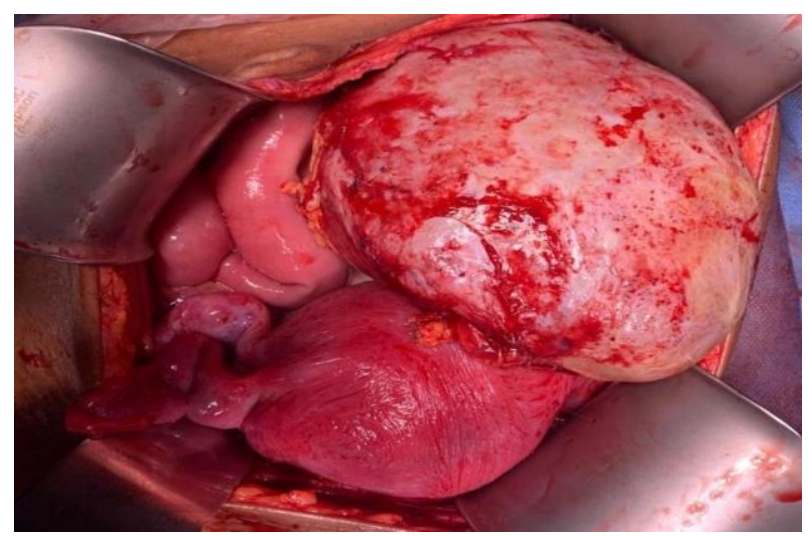

Figure 4: Per operative finding of unilocular ovarian cyst with polypoidal growth.

\section{DISCUSSION}

Detection rates of adnexal masses during pregnancy have increased with use of routine obstetrics ultrasound. It is estimated that $1 \%$ of all pregnancies are diagnosed with adnexal masses. ${ }^{7}$ While majority of these regress spontaneously, there is a risk of torsion, rupture, dystocia and rare chances of being malignant. Literature search has shown that around majority of adnexal masses with size less than $5 \mathrm{~cm}$ undergo complete resolution. ${ }^{8}$

In current case series, we analysed six cases of adnexal masses in pregnancy, diagnosed either during pregnancy or incidentally during caesarean section. In our study, all the women were below 30 years similar to that a study by Sayin et al wherein 4 out of six cases with adnexal masses in pregnancy were below 30 years. ${ }^{9}$ Whitecar et al in their cohort of 130 cases reported a mean age of 26.1 years. ${ }^{5}$ All the six cases in our study were unilateral similar to that seen by Fatema et al and Ulker et al. ${ }^{10,11}$

The most common and serious complication of benign ovarian cysts during pregnancy remains torsion of the cyst which is more prevalent in larger cysts. Yen et al in their series of 174 women reported a higher risk of torsion in cysts measuring $6-8 \mathrm{~cm}$ in size. ${ }^{12}$ During first and early second trimester owing to increased uterine size, there occurs cephalad displacement of ovaries making them prone for sudden torsion. ${ }^{13} \mathrm{We}$ had one such case of torsion detected during third trimester of pregnancy. Lee et al in their analysis reported that almost $61 \%$ of torsions occurred in first trimester, $14 \%$ in second trimester, and rest in third trimester. ${ }^{14}$ In a series of 20 cases of pregnancy with adnexal masses, torsion was detected in $25 \%$ cases. $^{15}$

Incidence of cyst rupture remains low generally less than $1 \% .^{5}$ Labour dystocia is another concern leading to increased caesarean rates. In our series, all cases underwent caesarean section, though the reason was obstetric indication. Cancer during pregnancy is rare with incidence of 0.02 to $1 \% .{ }^{16}$ No case of malignant ovarian mass was reported in current series. Timing of surgery depends on urgency of situation. Incidentally detected adnexal masses during caesarean delivery need excision at times to exclude malignancy. Care must be taken to avoid rupture during surgery. The American college of obstetricians and gynecologists committee opinion on nonobstetric surgeries during pregnancy states that emergency surgeries should be carried out irrespective of gestational age whereas those that cannot be delayed until after delivery need to undergo surgery in second trimester preferably to avoid miscarriage risk in first trimester and premature delivery in third trimester. ${ }^{17}$

Mature cystic teratoma was most common variety of adnexal mass diagnosed in our study. Whitecar et al reported $30 \%$ of cases as mature cystic teratomas whereas another study by Kumari et al showed serous cystadenoma $(20 \%)$ to be commonest occurring adnexal mass followed by mature cystic teratoma. ${ }^{5,15}$ No neonatal complications were noted due to presence of adnexal masses in our series. Out of the 2 preterm deliveries in our study, only one patient had preterm delivery due to adnexal mass undergoing torsion. The cause for preterm delivery of second patient was unrelated to ovarian cyst.

\section{CONCLUSION}

Mature cystic teratoma was the most common adnexal mass detected in our series. Ultrasound, MRI and tumor markers have to be considered in any patient with adnexal mass detected during pregnancy in order to exclude malignancy and for judicious management. Asymptomatic/small/unilocular cyst with low suspicion should be kept under observation and follow up throughout pregnancy. Any adnexal mass found incidentally during caesarean section must be removed.

\section{Funding: No funding sources \\ Conflict of interest: None declared \\ Ethical approval: Not required}

\section{REFERENCES}

1. Spencer CP, Robarts PJ. Management of adnexal masses in pregnancy. Obstetric Gynaecol. 2006;8(1): 14-9

2. Graham GM. Adnexal masses in pregnancy: diagnosis and management. Donald Sch J Ultrasound Obstetrics and Gynecol. 2007;1(4):66-74.

3. Cavaco-Gomes J, Jorge Moreira C, Rocha A, Mota R, Paiva V, Costa A. Investigation and Management of Adnexal Masses in Pregnancy. Scientifica (Cairo). 2016;2016:3012802.

4. Cunningham FG, Leveno KJ, Bloom SL, Hauth JC, Rouse DJ, Spong CY. Reproductive tract abnormalities. 23rd ed. New York: McGraw-Hill; 2010:912-25 
5. Whitecar MP, Turner S, Higby MK. Adnexal masses in pregnancy: A review of 130 cases undergoing surgical management. Am J Obstet Gynecol. 1999; $181: 19-24$

6. Gasim T, Al Dakhiel SA, Al Ghamdi AA. Ovarian tumors associated with pregnancy: a 20-year experience in a teaching hospital. Arch Gynecol Obstet. 2010;282(5):529-33.

7. Goh W., Bohrer J., Zalud I. Management of the adnexal mass in pregnancy. Curr Opin Obstet Gynecol. 2014;26:49-53.

8. Yacobozzi M, Nguyen D, Rakita D. Adnexal masses in pregnancy. Semin Ultrasound CT MR. 2012;33: 55-64.

9. Sayin NC, Inal HA, Varol FG. Pregnancies complicated by adnexal masses: a case series. Arch Gynecol Obstet. 2008;278(6):573-7.

10. Fatema N. Management and outcomes of ovarian masses measuring $\geq 5 \mathrm{~cm}$ in pregnancy - a series of six cases. MOJ Clin Med Case Rep. 2016;5(3):4519.

11. Ulker V, Gedikbasi A, Numanoglu C, Saygi S, Aslan $\mathrm{H}$, Gulkilik A. Incidental adnexal masses at cesarean section and review of literature. J Obstet Gynaecol Res. 2010;36(3):502-5

12. Yen C-F, Lin S-L, Murk W. Risk analysis of torsion and malignancy for adnexal masses during pregnancy. Fertil Steril. 2009;91:1895-902
13. Koo Y-J, Kim T-J, Lee J-E. Risk of torsion and malignancy by adnexal mass size in pregnant women. Acta Obstet Gynecol Scand. 2011;90:35861.

14. Lee GSR, Hur SY, Shin JC. Elective vs. conservative management of ovarian tumors in pregnancy. Int $\mathbf{J}$ Gynaecol Obstet. 2004;85:250-4

15. Kumari I, Kaur S, Mohan H, Huria A. Adnexal masses in pregnancy: a 5-year review. Aust N Z J Obstet Gynaecol. 2006;46(1):52-4.

16. Pavlidis N. Coexistence of pregnancy and malignancy. Oncol. 2002;7:279-87

17. ACOG committee on obstetric practice. ACOG committee opinion no. 474: non obstetric surgery during pregnancy. Obstet Gynecol. 2011;1172:14201 .

Cite this article as: Bahadur A, Sri MS, Mundhra R, Chawla L, Ajmani M, Afreen T, et al. Pregnancy with adnexal masses: an institutional experience and review of the literature. Int J Reprod Contracept Obstet Gynecol 2021;10:1148-53. 